\title{
Corporate Social Responsibility: A Cutting Edge Insight
}

\section{Towseef Ahmad}

Towseef Ahmad, Department of Law, University of Kashmir, Srinagar, India

\begin{abstract}
Corporate Social Responsibility has been analysed and debated for many decades and a plethora of approaches have emerged. This short flyer is assayed to review and assess that modern stakeholder businessmen are aware that a good public image contributes to the growth of their business houses. This appification and amplification of the conceptual framework of Corporate Social Responsibility by the galaxy of authors who have made outstanding and alternant contribution to it, echoes the distinguishing and growing significance of its purpose around the gazebo of sustainability. It rightly appears to be a precious human enterprise beyond reckoning.
\end{abstract}

\section{Publication History:}

Received: February 01, 2016

Accepted: April 09, 2016

Published: April 11, 2016

\section{Keywords:}

CSR, Environment, Society, Business, Stakeholder

\section{Introduction}

The eminent theorists who enriched the idea of Corporate Social Responsibility include H.R. Bowen, R.E. Freeman, A.B. Carroll, Donaldson and Preston and galaxy of authors who have made phenomenal contribution to the concept and dynamic philosophy of Corporate Social Responsibility \& Corporate Sustainability.

The variety of innovative and cutting edge perceptions about CSR can be explained by a number of factors via individual characteristics such as dedication and evaluation of personal values to organisational characteristics such as firm size and organisational expertise; and environmental factors such as cultural paradigm and institutional objectives. Business enterprises and corporate houses do have an ability to undertake a number of socially responsive roles and initiatives. According to IPSOS-Reuters Survey (2013), in global terms majority 'Strongly Agrees' that companies should pay more attention to the environment $(61 \%)$ and contribute more to society. (52\%). The implications of this kind of reporting appear to advance a new worldwide pluralistic governance and business pluralism.

Corporations should refrain from undermining the scientific temper of the business community. It is unfortunately happening that some corporate enterprises indulge in worst kinds of scams, scandals and nefarious activities and are therefore found to be wanting in collaborating towards the protection of environment, contribution to employee satisfaction and the goal of Corporate Social Responsibility. It should rather have been realized that CSR is a reservoir of a plethora of positive outcome. Stakeholder capitalism and integrated strategies enrich the movement of Corporate Social Responsibility. Stakeholders are satisfied with a company that meets their demands and expectations timely.

These dynamic attributes of Corporate Social Responsibility encourage us to suggest and hold the view that the practice of CSR is a very fascinating and a motivating task. An angle of perception which caters to the maximum benefit for the maximum number should be developed in the right utilitarian shaman. A utilitarian application is the raison dêtre of such practices because a Corporation is a blend of both competitive and cooperative utility. It is an instrumental house which seeks to balance the activities and managerial role of the Corporations, towards the environment and the society. Every moral right has a correlative moral duty [1]. Thence their famous work, assumes a great significance from the perspectives of business, society and law.

\section{Perspectives from Law, Society, and Business}

Business is a part of the society and survives on the demands of the society. Therefore it should be responsive to social expectations and welfare. Corporate conscience influences a number of benefits for the business entity through different modes.CSR increases the internal rate of return and improves the working conditions of shareholders within the Corporation.CSR fosters an advanced level of development to the human rights, labour, society and the environment by increasing the degree of participation of stakeholders in the company through global compact and several other operational frameworks.CSR has a positive impact on the public image of the company by strengthening public relations and communication strategies. It influences the approach of consumers of a company with delivery of durable services. These practices are regarded as a sign for enduring and persisting with correct strategies [2].

In India, a further influence appears to have been the Constitution. There is a veritable model of excellence under the Constitution of India. Fundamental rights, Directive Principles of State Policy and Fundamental Duties provide a thought provoking responsibility to its citizens. At the same time voluntary initiatives mark the beginning of a modern dawn of civilization in the 21 st century.

Law determines the responsibilities for its citizens. Law makes us do things we may not want to do. It is the voluntary action which adds light to the debate. It becomes the most noticeable feature of CSR. The legal discourse at the intersection of these views reveals a social dimension of Corporate Social Responsibility that transcends the confines of profits. The law demands that we pay taxes even when we have better uses for our money and think the taxes unwise.

It is to augur, that the underlying rationale is that the Corporations have to comply with the requirements and mandates of law, but they can undertake voluntary actions, initiatives and programmes on their own as well. This flexibility is statutory in India. It rightly appears to be precious beyond reckoning [3].

"Corresponding Author: Towseef Ahmad, Towseef Ahmad, Department of Law, University of Kashmir, Srinagar, India; E-mail: towseefahmad7@gmail.com

Citation: Ahmad T (2016) Corporate Social Responsibility: A Cutting Edge Insight Int J Earth Envrion Sci 1: 103. doi: http://dx.doi.org/10.15344/ijees/2016/103

Copyright: @ 2016 Ahmed. This is an open-access article distributed under the terms of the Creative Commons Attribution License, which permits unrestricted use, distribution, and reproduction in any medium, provided the original author and source are credited. 
Corporate Social Responsibility is placed both under mandatory and voluntary scenario. Rating and reporting agencies should try to foster a vibrant institutional mechanism by appreciating and rewarding the commendable work of entrepreneurs. In the same manner, collaborative CSR efforts among different business entities should be reviewed and channelized from time to time through newer and reliable indices.

\section{Trends, Intrepids \& Summum Bonum}

Awareness initiatives are a boon to every kind of society. Programmes like Swachh Bharat are to be utilized efficiently in this direction. Citizen Journalists can play their role to save the environment, biodiversity and rich culture and heritage of the country. Scientific temper must be cherished in the youth. In order to stomach the voluntary and enduring view, we should have a fulsome vision and act with wisdom. Thence, a feeling of such standards must exist around the hedge, wedge and edge of this phenomenon.

\section{Conclusion}

Corporate Social Responsibility is now an important concern for the corporations across the globe with a lot of forceful advocates. It is nurtured variedly by different countries and corporations. Thus, the concept is highly contextualized. Corporations require to co-ordinate and cooperate their CSR activities as portrayed by Donaldson and Preston. Firms should obey the law, perform their basic moral obligations and demonstrate their commitment to environment \& society, as forecasted by IPSOS-Reuters Survey. The long-standing debate over Corporate Social Responsibility will continue to limelight. There are a plethora of complex issues related to Corporate Social Responsibility that makes it a social as well as a legal debate. So the views presented here are just the tip of the iceberg on Corporate Social Responsibility.

\section{References}

1. Atupare PA (2014) Reconciling Socioeconomic Rights and Directive Principles with a Fundamental Law of Reason in Ghana and Nigeria. Harvard Human Rights $\mathrm{J} 27$.

2. IPSOS-Reuters Survey (2013)

3. Fontaine C, Haarman A, Schmid S (2006) The Stakeholder Theory.

4. Nwanji IT, Howell EK (2007) The Stakeholder Theory in the Modern Global Business Environment. Int J App Inst Gov 1. 